\title{
EVALUASI KENYAMANAN TERMAL \\ RUANG PERKULIAHAN GEDUNG ARSITEKTUR POLITEKNIK NEGERI SAMARINDA
}

\author{
Mafazah Noviana ${ }^{1}$ \\ ${ }^{1}$ Staf Pengajar Jurusan Desain, Prodi Arsitektur, Politeknik Negeri Samarinda \\ Email:mafazah79@gmail.com \\ Zakiah Hidayati ${ }^{2}$ \\ ${ }^{2}$ Staf Pengajar Jurusan Desain, Prodi Arsitektur, Politeknik Negeri Samarinda \\ Email: zakitec@yahoo.co.id
}

\begin{abstract}
Abstrak
Menciptakan lingkungan termal yang nyaman bagi manusia yang berada di dalamnya merupakan hal yang penting, karena dapat mempengaruhi sikap dan kinerja dari individu bahkan keselaman individu tersebut. Oleh karena itu studi terhadap kenyamanan termal dengan objek ruang perkuliahan dan penggunanya ini sangat penting dilakukan, untuk mengetahui tingkat kenyamanan sebagian besar pengguna dalam hal ini mahasiswa yang berada dalam ruangan, sehingga dapat diperoleh rekomendasi perbaikan ruang perkuliahan yang nyaman dalam mendukung proses belajar yang lebih baik. Program Studi Arsitektur merupakan salah satu program studi yang ada di Jurusan Desain Politeknik Negeri Samarinda. Sejak tahun 2014 Program Studi Arsitektur telah melaksanakan kegiatan belajar mengajar di gedung sendiri, yang terdiri dari 3 lantai. Metode penelitian yang digunakan dalam kajian ini adalah metode penelitian deskriptif baik kualitatif maupun kuantitatif. Metode kualitatif yaitu metode penelitian yang berusaha menggambarkan objek sesuai dengan kenyataan melalui pengamatan (observasi). Metode kuantitatif yang digunakan berupa pendekatan dengan menggunakan alat ukur dan mengolah hasil pengukuran tersebut ke dalam grafik untuk mengetahui kenyamanan termal ruang. Lokasi penelitian yaitu 6 ruang perkuliahan di Gedung Arsitektur POLNES. Hasil yang diperoleh menunjukkan bahwa kondisi termal di beberapa ruang kuliah belum memenuhi standar kenyamanan sehingga perlu dilakukan upaya pengkondisian udara.
\end{abstract}

Kata kunci: kenyamana, termal, ruang

\section{PENDAHULUAN}

Kota Samarinda beriklim tropis basah, hujan sepanjang tahun. Temperatur udara antara $20^{\circ} \mathrm{C}-34^{\circ} \mathrm{C}$ dengan curah hujan rata-rata per tahun $1980 \mathrm{~mm}$, sedangkan kelembaban udara rata-rata $85 \%$.

Berdasarkan data tersebut dapat dikatakan bahwa Samarinda memiliki temperatur yang panas, lembab dengan curah hujan yang cukup tinggi. Hal ini berpengaruh pada semua aktifitas manusia terutama 
Vol. 3, No. 1, Oktober 2015

yang dilakukan di dalam ruangan misalnya: bekerja, tidur dan belajar.

Kenyamanan lingkungan sekitar pada saat terjadinya proses belajar dan mengajar merupakan faktor penting yang dapat mempengaruhi hasil belajar yang dilakukan oleh individu. Salah satu faktor kenyamanan lingkungan yang mempengaruhi tingkat kenyamanan pada saat seseorang bekerja adalah kenyamanan termal. Menurut ASHRAE (American Society of Heating, Refrigerating and Airconditioning Engineers, 1989), kenyamanan termal merupakan perasaan dimana seseorang merasa nyaman dengan keadaan temperatur lingkungannya, yang dalam konteks sensasi digambarkan sebagai kondisi dimana seseorang tidak merasakan kepanasan maupun kedinginan pada lingkungan tertentu.

Program Studi Arsitektur merupakan salah satu program studi yang ada di Jurusan Desain Politeknik Negeri Samarinda. Sejak tahun 2014 Program Studi Arsitektur telah melaksanakan kegiatan belajar mengajar di gedung sendiri, yang terdiri dari 3 lantai. Di gedung arsitektur terdapat 6 ruang yang digunakan untuk perkuliahan, lainnya adalah ruang-ruang pendukung kegiatan belajar diantaranya kantor, ruang studio, laboratorium dan galeri.

Menciptakan lingkungan termal yang nyaman bagi manusia yang berada di dalamnya merupakan hal yang penting, karena dapat mempengaruhi sikap dan kinerja dari individu bahkan keselamatan individu tersebut. Oleh karena itu studi terhadap kenyamanan termal dengan objek ruang perkuliahan dan penggunanya ini sangat penting dilakukan, untuk mengetahui tingkat kenyamanan sebagian besar pengguna dalam hal ini mahasiswa yang berada dalam ruangan, sehingga dapat diperoleh rekomendasi perbaikan ruang perkuliahan yang nyaman dalam mendukung proses belajar yang lebih baik.

\section{KAJIAN PUSTAKA}

Salah satu faktor lingkungan fisik yang mempengaruhi tingkat kenyamanan pada saat bekerja adalah kenyamanan termal. Menurut American Society of Heating, Refrigerating and Air-conditioning Engineers/ASHRAE (1989), kenyamanan termal adalah perasaan dimana seseorang merasa nyaman dengan keadaan temperatur lingkungannya, yang dalam konteks sensasi digambarkan sebagai kondisi dimana seseorang tidak merasakan kepanasan maupun kedinginan pada lingkungan tertentu. Kenyamanan termal menurut ASHRAE (1989):

(1) Temperatur udara, merupakan temperatur di sekeliling individu. Bisa dikatakan salah satu faktor utama dari kenyamanan termal; (2) Temperatur radiant, adalah panas yang beradiasi dari objek yang mengeluarkan panas. Temperatur radiant lebih memberikan pengaruh yang lebih besar dibandingkan temperatur udara dalam bagaimana kita melepas atau menerima panas dari atau ke lingkungan; (3) Kecepatan angin, merupakan faktor yang penting dalam kenyamanan termal. Udara yang tidak bergerak dalam ruangan tertutup akan menyebabkan pengguna ruangan merasa kaku ataupun berkeringat; (4) Kelembaban Udara, Kelembaban relatif adalah perbandingan antara jumlah uap air pada udara dengan jumlah maksimum uap air yang udara bisa 
Mafazah Noviana, Zakiah Hidayati, Evaluasi Kenyamanan Termal Ruang Perkuliahan Gedung Arsitektur Politeknik Negeri Samarinda

ditampung pada temperatur tersebut. Lingkungan yang mempunyai kelembaban relatif tinggi mencegah penguapan keringat dari kulit. Di lingkungan yang panas, semakin sedikit keringat yang menguap karena kelembaban tinggi, sehingga kegerahan bagi individu yang berada di lingkungan tersebut; (5) Insulasi pakaian, Kenyamanan termal sangat dipengaruhi oleh efek insulasi pakaian yang kita kenakan. Pakaian mengurangi pelepasan panas tubuh. Karena itu, pakaian diklasifikasikan berdasarkan pada nilai insulasinya; (6) Tingkat metabolisme, merupakan panas yang dihasilkan di dalam tubuh sepanjang beraktivitas. Semakin banyak melakukan aktivitas fisik, semakin banyak panas yang dibuat. Semakin banyak panas yang dihasilkan tubuh, semakin banyak panas yang perlu dihilangkan agar tubuh tidak mengalami overheat.

Temperatur menyeluruh suatu ruangan selama masih dalam batas kenyamanan maka tidak akan ada masalah, namun jika sudah di luar batas kenyamanan maka menjadi suatu gangguan bahkan menimbulkan efek psikologis ataupun fisiologis tergantung pada level pertukaran panasnya. Menurut Sutalaksana, dkk (1979) berbagai tingkat temperatur akan memberikan pengaruh yang berbeda-beda sebagai berikut: (a) $49^{\circ} \mathrm{C}$ : Temperatur yang dapat ditahan sekitar 1 jam, tetapi jauh diatas tingkat kemampuan fisik dan mental. Lebih kurang $30^{\circ}$ derajat Celcius: aktivitas mental dan daya tanggap mulai menurun dan cenderung untuk membuat kesalahan dalam pekerjaan. Timbul kelelahan fisik; (b) $\pm 30^{\circ} \mathrm{C}$ : Aktivitas mental dan daya tanggap mulai menurun dan cenderung untuk membuat kesalahan dalam pekerjaan, timbul kelelahan fisik; (c) $\pm 24^{\circ} \mathrm{C}$ : Kondisi optimum; (d) $\pm 10^{\circ} \mathrm{C}$ : Kelakuan fisik yang ekstrem mulai muncul.

Untuk mengetahui kondisi kenyamanan ruang, dapat digunakan perhitungan kenyamanan termal antara lain indeks PMV (Predicted Mean Vote) dimana merupakan teori kenyamanan termal yang memprediksi kenyamanan termal seseorang. Indeks PPD (Predicted Percentage of Dissatisfied) digunakan untuk memprediksi berapa banyak orang yang meras a tidak nyaman dari suatu kondisi termal di dalam suatu ruangan. Indeks PMV (Predicted Mean Vote) adalah model yangmenghubungkan antara sensasi termal dengan kombinasi dua variable dan empat variable iklim (Fanger,1982 sebagaimana ditulis dalam Sugini 2014).
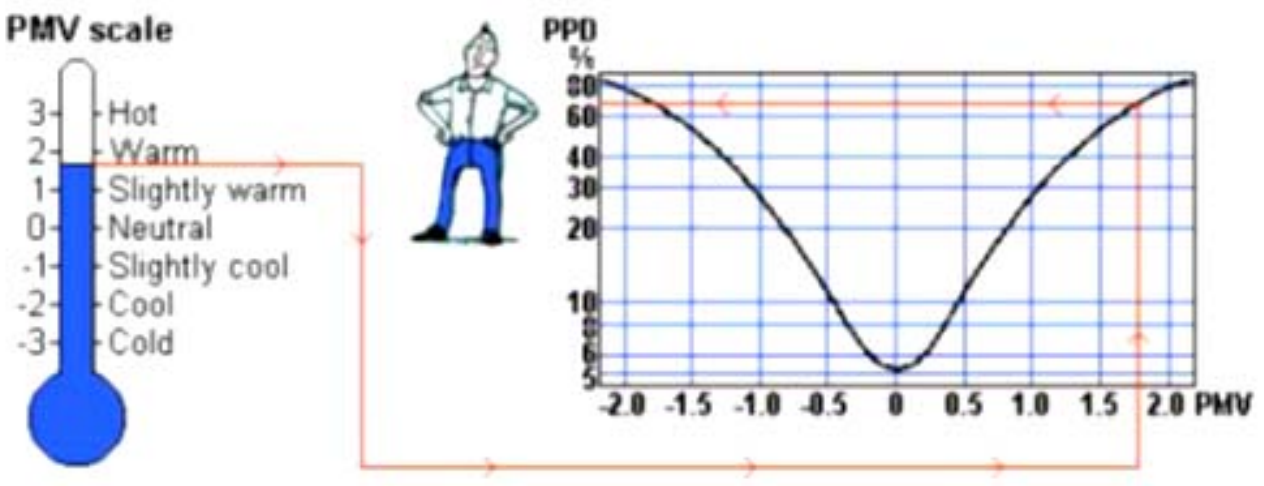

Gambar 1. Hubungan antara PMV dan PPD Hubungan antara PMV dan PPD 34 
Vol. 3, No. 1, Oktober 2015

Marsidi dan Ch. Desi Kusmindari (2009), dalam jurnalnya yang berjudul Pengaruh Tingkat Kelembaban Nisbi Dan Suhu Ruang Kelas Terhadap Proses Belajar, juga mengemukakan bahwa salah satu pertimbangan yang perlu diperhatikan dalam mendukung proses belajar mengajar adalah lingkungan belajar, tempat terjadinya proses belajar mengajar, dimana salah satu variabel yang menjadi pertimbangan adalah kondisi iklim di ruang kelas (kelembaban nisbi atau relatif dan temperatur).

Santoso (2012) menyatakan

Pada bangunan-bangunan di daerah dengan iklim tropis lembab banyak mengalami kesulitan untuk memenuhi standar yang disyaratkan sesuai zona kenyamanan ASHRAE 55. Hal ini disebabkan karena variabel yang mempengaruhi kenyamanan termal kurang mendukung, diantaranya suhu udara, kelembaban relatif, radiasi sinar matahari dan kecepatan udara dalam ruang. Untuk mencapai kenyamanan termal yang diinginkan perlu dilakukan kontrol atau tindakan adaptif dari penghuni diantaranya dengan mengatur sistim ventilasi, mengatur sirkulasi angin secara mekanik, memberikan tirai pada bagian bangunan yang langsung terkena radiasi matahari bahkan disarankan untuk membuat disain perangkat shading matahari untuk meminimalkan panas radiasi.

Menurut Rilatupa (2008) berdasarkan penelitiannya yang berjudul Aspek Kenyamanan Termal pada Pengkondisian Ruang Dalam disimpulkan bahwa peran arsitektur sangat mendukung kenyamanan termal ruang. Penataan bangunan dan ruang sebaiknya memperhatikan kondisi iklim dan alam setempat; sehingga dapat meminimalkan ketidaknyaman ruang.

\section{METODE PENELITIAN}

Metode penelitian yang digunakan dalam kajian ini adalah metode penelitian deskriptif baik kualitatif maupun kuantitatif. Metode kualitatif yaitu metode penelitian yang berusaha menggambarkan objek sesuai dengan kenyataan melalui pengamatan (observasi). Metode kuantitatif yang digunakan berupa pendekatan dengan menggunakan alat ukur dan mengolah hasil pengukuran tersebut ke dalam grafik. Penelitian dilakukan di ruang-ruang perkuliahan Gedung Arsitektur POLNES, yang terdiri dari 6 ruang kuliah, yaitu ruang kuliah semester I A, I B, IIIA, III B, V A, V B. Ruang perkuliahan dipilih karena sebagian besar kegiatan belajar mengajar berlangsung di tempat ini.

Untuk mendapatkan data tentang temperatur baik DBT (Dry Bulb Temperature), WBT(Wet Buld Temperature), maupun $\mathrm{RH}$ (Relative Humidity) dan kecepatan pergerakan udara, pengukuran dilakukan pada titik-titik dalam ruang.

Pengamatan, pengukuran dimensi dan pencatatan dilakukan terhadap besaran-besaran dan luas ruang, dimensi bukaan, dan volume ruang.

Pengumpulan data melalui perhitungan: selain data primer tersebut di atas juga dilakukan perhitungan-perhitungan atau penggunaan diagram-diagram kenyamanan termal.

Pengukuran kondisi termal pada ruang-ruang perkuliahan dilakukan 3 (tiga kali) dalam satu hari yaitu jam 08.00, jam 11.00 dan jam 14.00 , dengan pertimbangan jam efektif berlangsungnya kegiatan 
Mafazah Noviana, Zakiah Hidayati, Evaluasi Kenyamanan Termal Ruang Perkuliahan Gedung Arsitektur Politeknik Negeri Samarinda

belajar mengajar. Parameter yang diukur adalah: temperatur kering (DBT), kelembaban (RH) dan kecepatan angin $(\mathrm{AV})$.

Untuk mengetahui kondisi kenyamanan termal ruangan digunakan perhitungan kenyamanan termal dengan indeks PMV (Predicted Mean Vote) dimana merupakan teori kenyamanan termal yang memprediksi kenyamanan termal seseorang. Setelah mendapatkan nilai indeks dari PMV maka diketahui berapa persentase orang memprediksi meras a tidak nyaman dari suatu kondisi termal di dalam suatu ruangan dengan menggunakan indeks PPD (Predicted Percentage of Dissatisfied). Nilai $P M V$ dan PPD dapat diperoleh dengan menggunakan salah satu program komputer yaitu $C B E$ Thermal Comfort Tool for ASHRAE-55.

\section{HASIL DAN PEMBAHASAN}

\section{Kondisi Eksisting Ruang Kuliah}

Kondisi ruang adalah keadaan suatu ruang yang mempengaruhi kondisi termal ruang, Untuk itu maka berikut ini akan dijabarkan kondisi eksisting masing-masing ruang kuliah.

\section{Ruang Kuliah Semester I A}

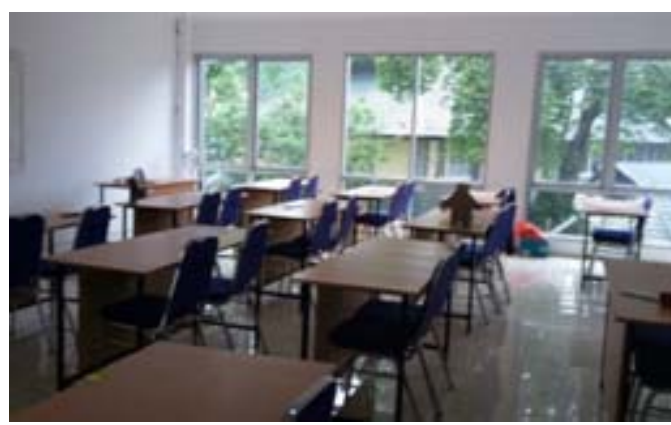

gambar 2

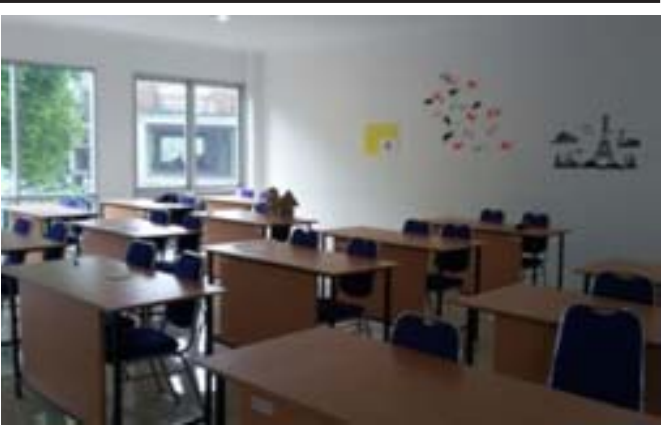

gambar 3

Gambar 2 - 3. Ruang Kuliah I A

Ruang kuliah semester I A terletak di lantai 3 Gedung Arsitektur. Kondisi ruang banyak terdapat bukaan alami berupa jendela kaca dengan kusen alumunium tanpa penutup (gorden). Ruang ini tidak memiliki penghawaan buatan baik berupa kipas angin maupun AC. Material dinding ruang menggunakan bata plester, plafon menggunakan gypsum.

\section{Ruang Kuliah Semester I B}

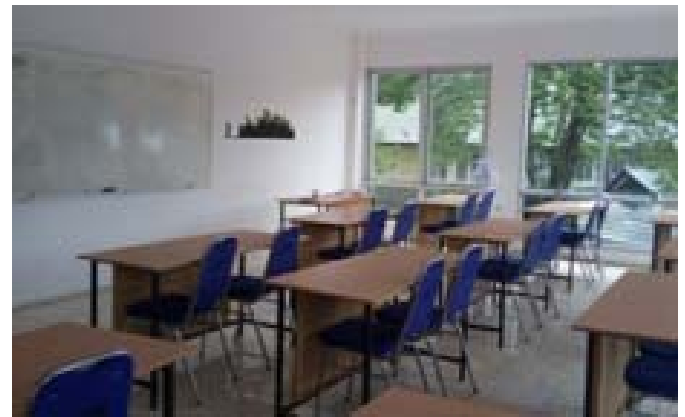

gambar 4

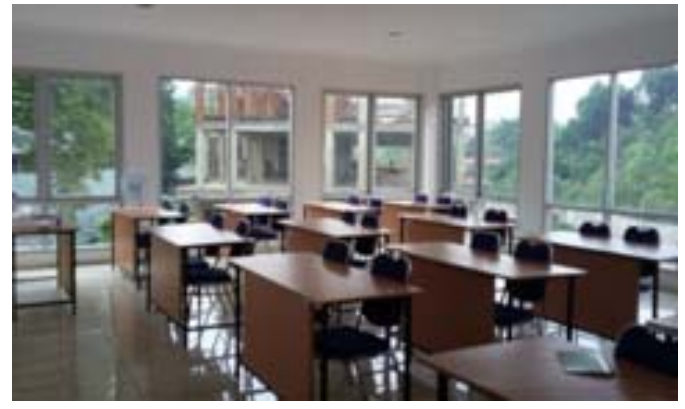

gambar 5

Gambar 4 - 5. Ruang Kuliah I B 
Ruang kuliah semester I B letaknya persis bersebelahan dengan ruang kuliah semester I A. Kondisi eksisting ruang hampir sama dengan ruang kuliah I A, perbedaannya yaitu memiliki jumlah jendela lebih banyak

\section{Ruang Kuliah Semester III A}

Ruang kuliah semester III A terletak di lantai 2 Gedung Arsitektur. Kondisi ruang banyak terdapat bukaan alami berupa jendela kaca dengan kusen alumunium tanpa penutup (gorden). Ruangan ini memiliki sebuah AC berukuran 1 pk sebagai penghawaan buatan. Material dinding ruang menggunakan bata plester, plafon menggunakan gypsum.

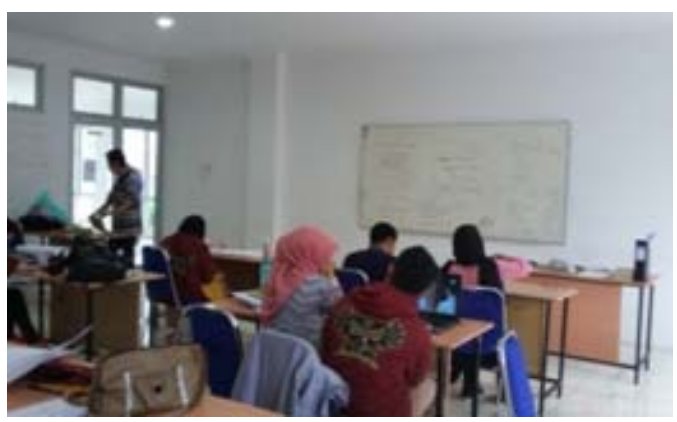

gambar 6

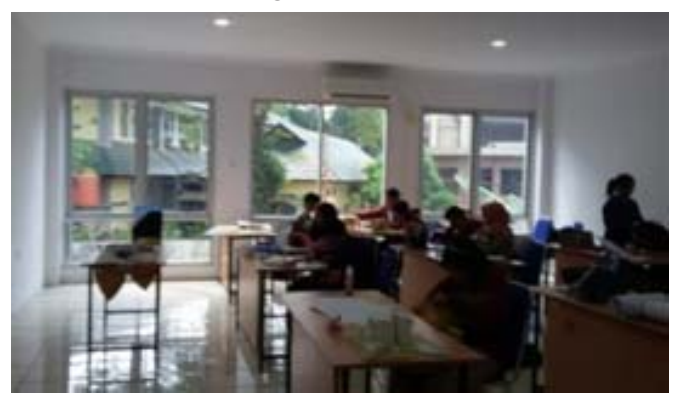

gambar 7

Gambar 6 - 7. Ruang Kuliah III A
4. Ruang Kuliah Semester III B

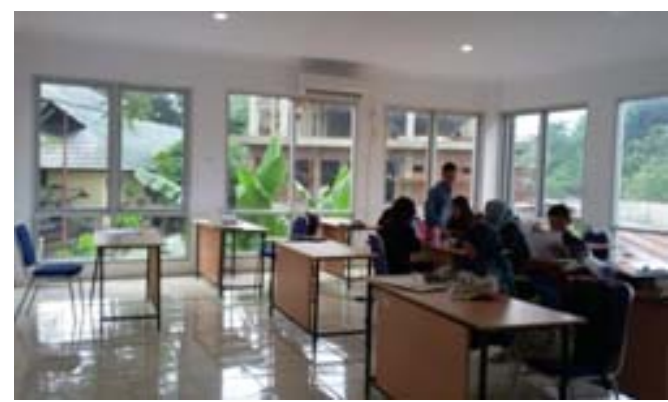

gambar 8

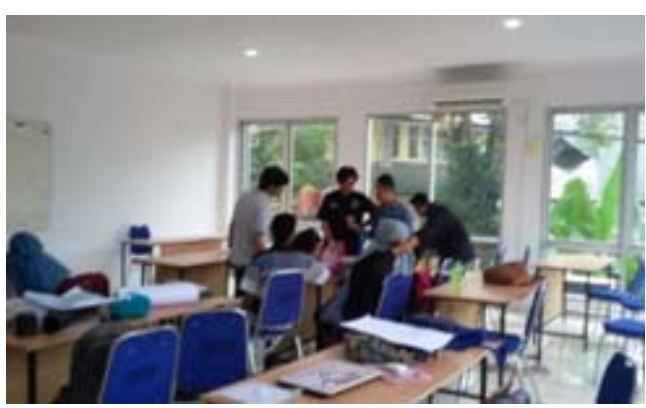

gambar 9

Gambar 8 - 9.Ruang Kuliah III B

Ruang kuliah semester III B letaknya persis di sebelah ruang kuliah semester III A. Kondisi eksisting ruang hampir sama dengan ruang kuliah III A, perbedaannya terletak pada jumlah jendela yang ada di ruangan ini lebih banyak, yaitu pada 2 sisi ruang.

\section{Ruang Kuliah Semester V A}

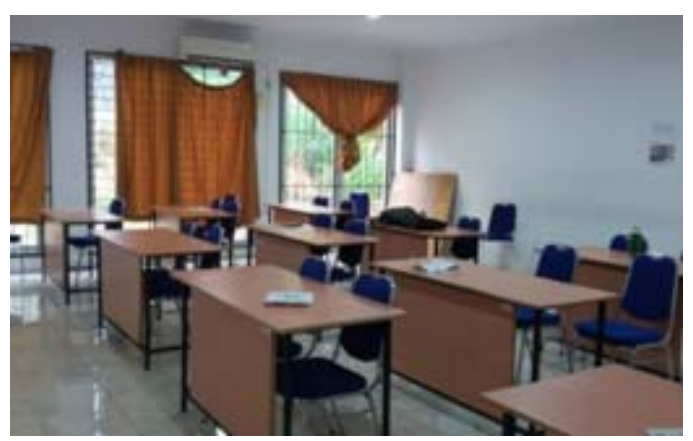

gambar 10 
Mafazah Noviana, Zakiah Hidayati, Evaluasi Kenyamanan Termal Ruang Perkuliahan Gedung Arsitektur Politeknik Negeri Samarinda

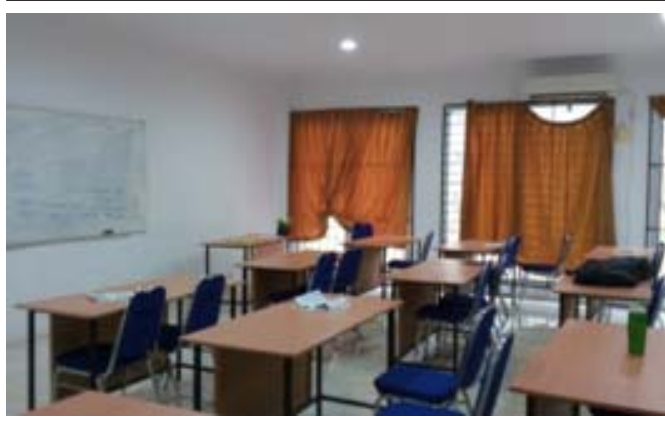

gambar 11

Gambar 10 - 11. Ruang Kuliah V A

Ruang kuliah semester V A terletak di lantai 1 Gedung Arsitektur. Kondisi ruang banyak terdapat bukaan alami berupa jendela kaca dengan kusen alumunium yang sehari-hari ditutupi gorden. Ruang ini memiliki sebuah AC berukuran $1 p k$ sebagai penghawaan buatan. Material dinding ruang menggunakan bata plester, plafon menggunakan gypsum.

\section{Ruang Kuliah Semester V B}

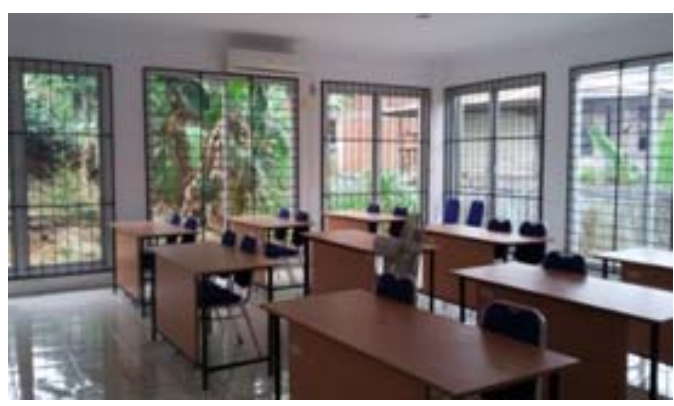

gambar 12

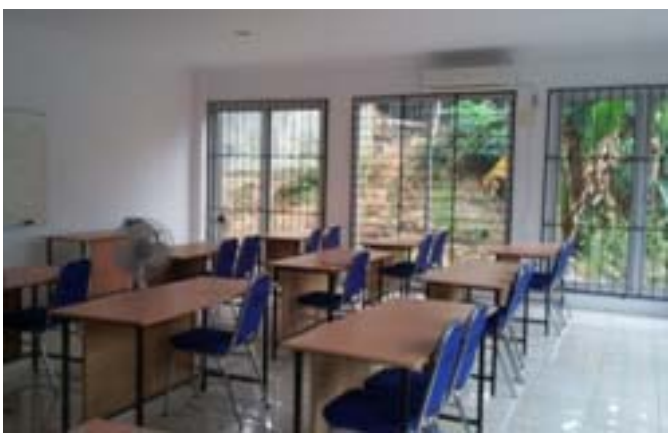

gambar 13

Gambar 12 - 13. Ruang Kuliah V B

Ruang kuliah semester V B terletak tepat di sebelah ruang kuliah $\mathrm{V}$ A. Kondisi eksisting ruang hampir sama dengan ruang $\mathrm{V}$ A, hanya saja jendela yang ada di ruang ini lebih banyak dan tidak ditutupi dengan gorden.

\section{Kondisi Termal Ruang Kuliah}

Pengukuran dilakukan pada 5 titik setiap ruang pada kondisi dengan menggunakan penghawaan alami kemudian dilakukan lagi pengukuran ruang dengan menggunakan penghawaan buatan.

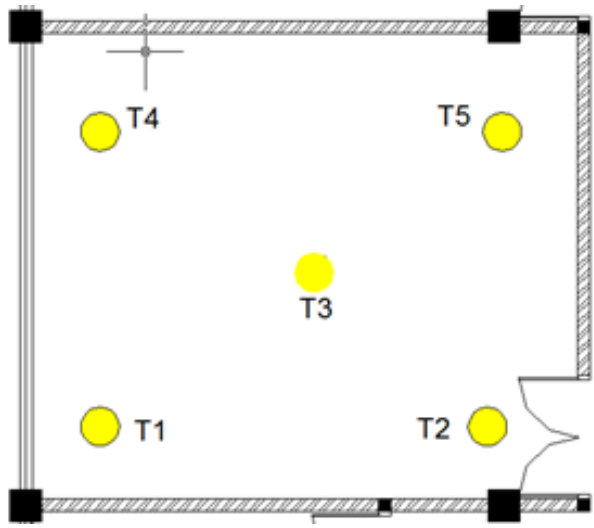

Gambar 14.

Titik pengukuran suhu dan kelembaban udara pada ruang kuliah

Dari hasil pergukuran tiap ruang kuliah di Gedung Arsitekur, didapatkan rekapitulasi data rata-rata temperatur dan kelembaban udara ruang kuliah dalam kondisi ruang dengan penghawaan alami maupun dengan penghawaan buatan. 
Vol. 3, No. 1, Oktober 2015

Tabel 1.

Rekapitulasi Data Rata-rata Temperatur Ruang Kuliah dengan Penghawaan

Alami

\begin{tabular}{|l|r|r|r|}
\hline \multirow{2}{*}{ RUANG } & \multicolumn{3}{|c|}{ WAKTU PENGAMAAN } \\
\cline { 2 - 4 } & $\mathbf{0 8 . 0 0 - 0 9 . 0 0}$ & $\mathbf{1 1 . 0 0 - 1 2 . 0 0}$ & $\mathbf{1 4 . 0 0 - 1 5 . 0 0}$ \\
\hline RUANG I A & 28.06 & 28.96 & 30.88 \\
\hline RUANG I B & 28.40 & 28.80 & 30.68 \\
\hline RUANG III A & 26.56 & 28.26 & 28.36 \\
\hline RUANG III B & 27.68 & 28.64 & 29.42 \\
\hline RUANG V A & 26.36 & 29.42 & 29.42 \\
\hline RUANG V B & 27.34 & 29.08 & 29.18 \\
\hline
\end{tabular}

Tabel 2.

Rekapitulasi Data Rata-rata Temperatur Ruang Kuliah dengan Penghawaan Buatan

\begin{tabular}{|c|r|r|r|}
\hline \multirow{2}{*}{ RUANG } & \multicolumn{3}{|c|}{ WAKTU PENGAMATAN } \\
\cline { 2 - 4 } & $\mathbf{0 8 . 0 0 - 0 9 . 0 0}$ & $\mathbf{1 1 . 0 0 - 1 2 . 0 0}$ & $\mathbf{1 4 . 0 0 - 1 5 . 0 0}$ \\
\hline RUANG III A & 25.18 & 26.96 & 27.66 \\
\hline RUANG III B & 27.16 & 27.46 & 27.70 \\
\hline RUANG V A & 25.98 & 27.68 & 27.62 \\
\hline RUANG V B & 25.88 & 26.52 & 28.02 \\
\hline
\end{tabular}

Tabel3.

Rekapitulasi Data Rata-rata Kelembaban Udara Ruang Kuliah dengan Penghawaan Alami

\begin{tabular}{|l|r|r|r|}
\hline \multirow{2}{*}{ RUANG } & \multicolumn{3}{|c|}{ WAKTU PENGAMATAN } \\
\cline { 2 - 4 } & $\mathbf{0 8 . 0 0 - 0 9 . 0 0}$ & $\mathbf{1 1 . 0 0 - 1 2 . 0 0}$ & $\mathbf{1 4 . 0 0 - 1 5 . 0 0}$ \\
\hline RUANG I A & 67.10 & 55.18 & 62.42 \\
\hline RUANG I B & 66.64 & 56.40 & 65.12 \\
\hline RUANG III A & 69.38 & 55.90 & 63.14 \\
\hline RUANG III B & 65.02 & 58.26 & 63.14 \\
\hline RUANG V A & 65.02 & 56.90 & 53.98 \\
\hline RUANG V B & 65.38 & 62.62 & 53.96 \\
\hline
\end{tabular}

Tabel 4.

Rekapitulasi Data Rata-rata Kelembaban Udara Ruang Kuliah dengan Penghawaan Buatan

\begin{tabular}{|c|r|r|r|}
\hline \multirow{2}{*}{ RUANG } & \multicolumn{3}{|c|}{ WAKTU PENGAMATAN } \\
\cline { 2 - 4 } & $\mathbf{0 8 . 0 0 - 0 9 . 0 0}$ & $\mathbf{1 1 . 0 0 - 1 2 . 0 0}$ & $\mathbf{1 4 . 0 0 - 1 5 . 0 0}$ \\
\hline RUANG III A & 60.40 & 56.02 & 57.80 \\
\hline RUANG III B & 57.58 & 50.68 & 63.48 \\
\hline RUANG V A & 57.58 & 48.52 & 60.56 \\
\hline RUANG V B & 53.02 & 55.82 & 48.56 \\
\hline
\end{tabular}


Mafazah Noviana, Zakiah Hidayati, Evaluasi Kenyamanan Termal Ruang Perkuliahan Gedung Arsitektur Politeknik Negeri Samarinda

Kenyamanan Termal Ruang Kuliah

Untuk mengetahui kondisi kenyamanan termal digunakan perhitungan kenyamanan termal dengan indeks PMV (Predicted Mean Vote) dimana merupakan teori kenyamanan termal seseorang. Setelah mendapatkan nilai indeks dari $P M V$ maka diketahui berapa persentasi orang memprediksi merasa tidak nyaman dari suatu kondisi termal di dalam suatu ruangan dengan menggunakan indeks PPD (Predicted Percentage of Dissatisfied). Perhitungan indeks $P M V$ dan $P P D$ menurut standar ASHRAE-55 menggunakan $C B E$ Thermal Comfort Tool. Kegiatan yang dilakukan di dalam ruang kuliah adalah kegiatan belajar mengajar $(\mathrm{M}$, met $=1$ ), dengan berpakaian ringan $(c l o=0,19)$.

Tabel 5.

Hasil Perhitungan PMV dan PPD dengan penghawaan alami

\begin{tabular}{|c|c|c|c|c|}
\hline \multirow{2}{*}{ RUANG } & WAKTU & PMV & $\begin{array}{c}\text { PPD } \\
\mathbf{( \% )}\end{array}$ & PERSEPSI \\
\hline \multirow{3}{*}{ I A } & $08.00-09.00$ & 0.53 & 11 & Agak Panas \\
\cline { 2 - 5 } & $11.00-12.00$ & 0.8 & 19 & Agak Panas \\
\cline { 2 - 5 } & $14.00-15.00$ & 1.71 & 63 & Panas \\
\hline \multirow{3}{*}{ I B } & $08.00-09.00$ & 0.67 & 14 & Agak Panas \\
\cline { 2 - 5 } & $11.00-12.00$ & 0.75 & 17 & Agak Panas \\
\cline { 2 - 5 } & $14.00-15.00$ & 1.65 & 59 & Panas \\
\hline \multirow{3}{*}{ III A } & $08.00-09.00$ & -0.1 & 5 & Nyaman \\
\cline { 2 - 5 } & $11.00-12.00$ & 0.51 & 10 & Agak panas \\
\cline { 2 - 5 } & $14.00-15.00$ & 0.62 & 13 & agak panas \\
\hline \multirow{3}{*}{ III B } & $08.00-09.00$ & 0.34 & 7 & Nyaman \\
\cline { 2 - 5 } & $11.00-12.00$ & 0.69 & 15 & Agak panas \\
\cline { 2 - 5 } & $14.00-15.00$ & 1.08 & 30 & Agak panas \\
\hline \multirow{3}{*}{ V A } & $08.00-09.00$ & -0.22 & 6 & Nyaman \\
\cline { 2 - 5 } & $11.00-12.00$ & 1.02 & 27 & Agak panas \\
\cline { 2 - 5 } & $14.00-15.00$ & 0.99 & 26 & Agak panas \\
\hline \multirow{3}{*}{ V B } & $08.00-09.00$ & 0.2 & 6 & Nyaman \\
\cline { 2 - 5 } & $11.00-12.00$ & 0.93 & 23 & Agak panas \\
\cline { 2 - 5 } & $14.00-15.00$ & 0.89 & 22 & Agak panas \\
\hline
\end{tabular}


Tabel 6.

Hasil Perhitungan PMV dan PPD dengan penghawaan buatan

\begin{tabular}{|c|c|c|c|c|}
\hline \multirow{2}{*}{ RUANG } & WAKTU & PMV & $\begin{array}{c}\text { PPD } \\
\mathbf{( \% )}\end{array}$ & PERSEPSI \\
\hline \multirow{3}{*}{ III A } & $08.00-09.00$ & -0.77 & 18 & Agak dingin \\
\cline { 2 - 5 } & $11.00-12.00$ & -0.04 & 5 & Nyaman \\
\cline { 2 - 5 } & $14.00-15.00$ & 0.03 & 5 & Nyaman \\
\hline \multirow{3}{*}{ III B } & $08.00-09.00$ & 0.05 & 5 & Nyaman \\
\cline { 2 - 5 } & $11.00-12.00$ & 0.12 & 5 & Nyaman \\
\cline { 2 - 5 } & $14.00-15.00$ & 0.04 & 5 & Nyaman \\
\hline \multirow{3}{*}{ V A } & $08.00-09.00$ & -0.44 & 9 & Nyaman \\
\cline { 2 - 5 } & $11.00-12.00$ & 0.2 & 6 & Nyaman \\
\cline { 2 - 5 } & $14.00-15.00$ & 0.28 & 7 & Nyaman \\
\hline \multirow{3}{*}{ V B } & $08.00-09.00$ & -0.52 & 11 & Agak dingin \\
\cline { 2 - 5 } & $11.00-12.00$ & -0.23 & 6 & Nyaman \\
\cline { 2 - 5 } & $14.00-15.00$ & 0.11 & 5 & Nyaman \\
\hline
\end{tabular}

Penelitian ini memperlihatkan perbandingan kondisi termal ruang kuliah saat menggunakan penghawaan alami dan saat menggunakan penghawaan buatan. Kondisi seluruh ruang kuliah dengan penghawaan alami pada pagi hari (08.00 - 09.00) berada dalam kategori nyaman, sedangkan pada pengukuran pukul $11.00-12.00$ dan 14.00 - 15.00 kondisi termal ruang termasuk dalam kategori agak panas yang artinya ruangan kurang nyaman. Sedangkan pada saat ruang menggunakan penghawaan buatan, sebagian besar ruang termasuk dalam kategori nyaman atau netral, kecuali untuk ruang kuliah III A dan V B pada pagi hari $(08.00-09.00)$ termasuk dalam kategori agak dingin atau dapat dikatakan kurang nyaman.

Penggunaan pendingin udara untuk ruang kuliah cukup efektif untuk mengkondisikan ruangan menjadi lebih nyaman. Terbukti dari pengukuran dan penghitungan kenyamanan termal ruang yang telah dilakukan, menunjukkan sebagian besar ruang kuliah termasuk dalam kategori nyaman saat menggunakan pendingin udara, hanya pada pagi hari beberapa ruang menjadi agak dingin. Untuk mencapai kenyamanan termal suatu ruang dalam menggunakan pendingin udara semestinya harus dihitung terlebih dulu beban panas pendingin yang terdapat di dalam ruangan, seperti beban panas langit-langit, beban panas melalui lantai, beban panas penghuni, beban panas alat-alat listrik, beban panas perabot, sehingga dapat diketahui berapa energi yang dibutuhkan dalam menaikkan / menurunkan temperatur AC dalam ruang. 
Mafazah Noviana, Zakiah Hidayati, Evaluasi Kenyamanan Termal Ruang Perkuliahan Gedung Arsitektur Politeknik Negeri Samarinda

\section{KESIMPULAN DAN SARAN}

Berdasarkan hasil pembahasan yang telah diuraikan sebelumnya, dapat ditarik kesimpulan bahwa kondisi seluruh ruang kuliah dengan penghawaan alami pada pagi hari (08.00 - 09.00) berada dalam kategori nyaman, sedangkan pada pengukuran pukul $11.00-12.00$ dan 14.00 - 15.00 kondisi termal ruang termasuk dalam kategori agak panas yang artinya ruangan kurang nyaman. Sedangkan pada saat ruang menggunakan penghawaan buatan, sebagian besar ruang termasuk dalam kategori nyaman atau netral, kecuali untuk ruang kuliah III A dan V B pada pagi hari (08.00 - 09.00) termasuk dalam kategori agak dingin atau dapat dikatakan kurang nyaman.

Berdasarkan hasil penelitian ini disarankan Setiap ruang kuliah harus dilengkapi penghawaan udara buatan dengan menggunakan pendingin udara (AC) untuk mendapatkan kenyamanan termal yang efektif, tentunya dengan memperhatikan penggunaan energi yang seefisien mungkin. Dengan demikian kegiatan belajar mengajar dapat berjalan dengan lancar.

\section{DAFTAR PUSTAKA}

ASHRAE. 1989. Handbook of Fundamental Chapter 8: Physiological Principles, Comfort, and Health, ASHRAE, USA

Aprilia, Duhita. 2009. Kajian Eksperimen Pengaruh Interaksi Musik dan Temperatur Ruang Terhadap Kemampuan Kognitif. Skripsi Sarjana. Universitas Andalas, Indonesia.

Latifah, Nur Laela. Perdana, Harry. Prasetya, Agung. Siahaan, O P. 2011. Kajian Kenyamanan Termal Pada Bangunan Student Center ITENAS Bandung. Jurnal Teknik Arsitektur ITENAS

Marsidi dan Ch. Desi Kusmindari. 2009. Pengaruh Tingkat Kelembaban Nisbi Dan Suhu Ruang Kelas Terhadap Proses Belajar. Jurnal Ilmiah Tekno (2009) Vol 4.

Rilatupa, James. 2008. Aspek Kenyamanan Termal pada Pengkondisian Ruang Dalam. Jurnal Sains dan Teknologi EMAS, Vol. 18 No. 3 Agustus 2008.

Rahmadani, Dewi 2011. Evaluasi kenyamanan termal ruang perkuliahan di Universitas Andalas. Skripsi Sarjana. Universitas Andalas Padang.

Santoso, Eddy Imam. 2012. Kenyamanan Termal Indoor pada Bangunan di Daerah Beriklim Tropis Lembab. Indonesian Green Technology Journal.Vol. 1 No. 1.

Satwiko, Prasasto. 2008. Fisika Bangunan. Penerbit Andi. Yogyakarta. 